\title{
ADAPTATION OF FORGOTTEN BUILDINGS THE EXAMPLE OF THE RUINS OF THE KOŚCIELEC PROTESTANT CHURCH IN PIASKI
}

\author{
Piotr GLEN' ${ }^{1}$, Aleksandra JAROCKA-MIKRUT ${ }^{2}$ \\ Lublin University of Technology, \\ Faculty of Civil Engineering and Architecture, Lublin, Poland
}

\begin{abstract}
Small towns in the Lublin Province are abundant with buildings possessed of outstanding historical and architectural values, representing the culture of past generations. Piaski, about $30 \mathrm{~km}$ east of Lublin, also boasts some of the remarkable characteristic of small towns. Not only does it feature post-Jewish tenements, but also a palace and complexes of religious buildings situated on its outskirts. This article focuses on the Kościelec - an unused, dilapidated former Protestant church. Now, works are being carried out that have inspired the Piaski town authorities to try to find a best-use scenario for the former church, in order to preserve its architectural values for future generations. The authors of this article aim to prove the necessity of research and analysis in finding the best new functions for properties whose function has already been imposed. The example of successfully completed revitalisation works at the palace and park complex in Gardzienice, located not far from the baroque Protestant church in Piaski, illustrates the advantages of some of the adaptation processes that can be employed in such buildings.
\end{abstract}

Keywords: Protestant church, Polish Brethren, Piaski, Kościelec, revitalisation

\footnotetext{
${ }^{1}$ Corresponding author: Lublin University of Technology, Faculty of Civil Engineering and Architecture, Nadbystrzycka st 40, 20-618 Lublin, Poland,e-mail: p.glen@ pollub.pl, tel.+48815384454

2 a.jarocka@ pollub.pl, tel.+48815384454
} 


\section{INTRODUCTION}

Architecture has surrounded us for centuries. Inevitably, this is partly because over time, buildings appear around us whose best days are long past. This is closely related to how well they have been maintained, as well as what their original purpose was. The authors of this article intend to present such buildings' as they stand in the present. In the examples used in this paper, both from Poland and abroad, they will present successful attempts to introduce new functionalities to buildings whose original function was completely different. Over the centuries, religion has had a huge influence on the architecture of the world. Sacral architecture is not only about Christian churches, but also the great buildings and monuments in Egypt and Greece that were erected in the name of faith in gods. Some of the greatest architectural wonders were built for this reason, and it triggered the development of architectural styles and the building of ever-larger and richer temples. Competition to create the worthiest temples that could truly be called a House of God, further shaped architectural forms and promoted certain architectural novelties [3]. It is hard to imagine now any city without even one such glorious temple. Despite a general weakening of faith, the number of places for people to gather in its name is huge. In today's era of civilizational progress, the number of lay buildings deprived of their original function is also rising significantly. These include old industrial buildings, office buildings, as well as small buildings which were either never finished, or that have been abandoned without re-purposing.

The reasons for this are many and varied. So, instead of mass-producing new buildings, attention should instead be paid to adapting existing ones, often abandoned, yet sometimes having extraordinary potential.

\section{A NEED FOR A NEW FUNCTION}

Often, the need for new functionality in a building becomes a driving force for further development of the existing architecture. Historic buildings are frequently given modern features, without compromising the historic tissue forming their character and uniqueness.

One prime example from overseas of the transformation of a building's original sacral function to another is the Lumen United Reformed Church \& Community Centre URC in London, England (Fig. 1), designed by Theis and Khan Architects [4]. This religious building was adapted to become a place for leisure, a coffee shop. The introduction of the profanum to the sacrum could, at first, be shocking, but with time gives an impression of integral unity. The uniqueness and monumentality that accompanies religious architecture with 
new features complementing and penetrating the existing features, gives additional value to their perception. In this case, this was made possible by addressing a larger, more diverse audience than just member of the church. Adapting the 20th-century church building to the needs of the local community gave it a certain neutrality, significantly changing the perception of its architecture and new functions [4].

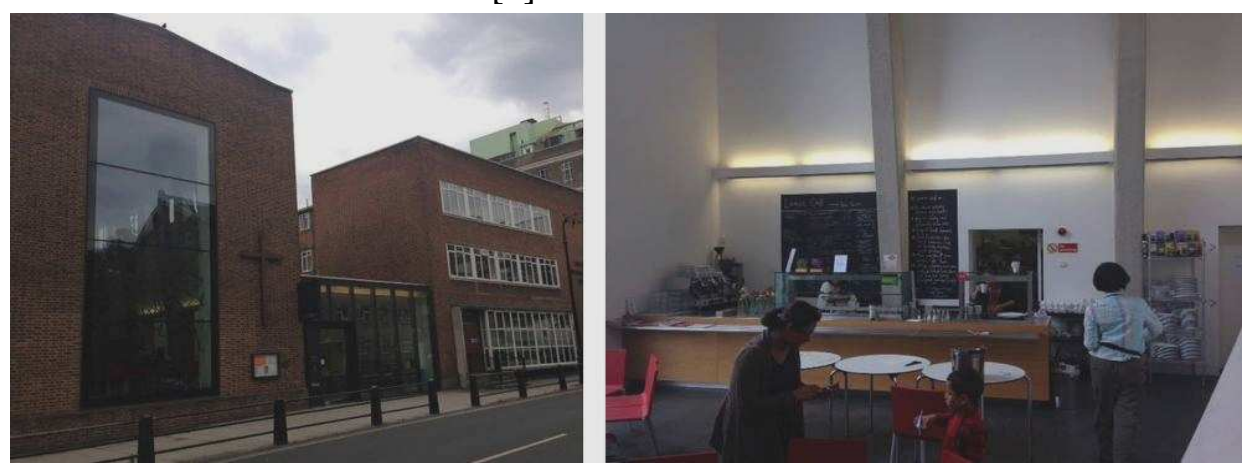

Fig. 1. The Lumen United Reformed Church \& Community Centre URC in London (author's photo)

Here in Poland, a hint of this kind of adaptation can be seen in the Alfa Shopping Center, at the intersection of A. Mickiewicz and Świętojańska streets in the northeastern city of Białystok. The conversion work done to the area and 19th century buildings of the old Becker factory now distinguishes this shopping centre from hundreds of others (Fig. 2), with historic elements of the former factory preserved and re-used in the new design. This combination of historic buildings with modern materials, so often encountered in many newlyadapted shopping centres, tends to be interesting and successful. The Alfa is an example of respect for an existing, historic structure that forms part of the character of the city.

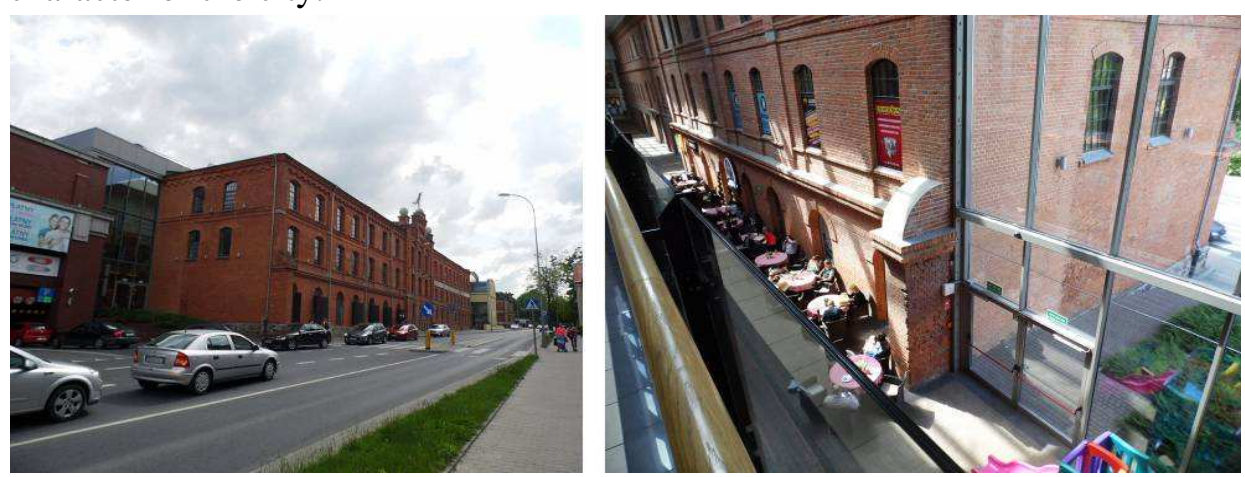

Fig. 2. Alfa Centrum Białystok (author's photo) 
Following the trail of the Lublin Renaissance style into the southeast of the country, the attention is caught by a historic palace and park complex in Gardzienice, near the city of Lublin itself, which has been adapted into the European Centre for Theatre Practices in Gradzienice Located on the Lublin Upland, the 17th century palace (Fig. 3) is considered by the Lubelskie Province's residents to be an integral part of the historic Jan III Sobieski Route [5]. And by complementing this historic building with theatre functions, it now attracts not only Polish art and theatre students, but also guests from abroad. With the fusion of these two purposes, visitors are introduced to a completely new space. The experience of the artistic and theatrical events presented by the Centre, within the context of what is already a unique building, is heightened through exploration of the entire palace and park complex.

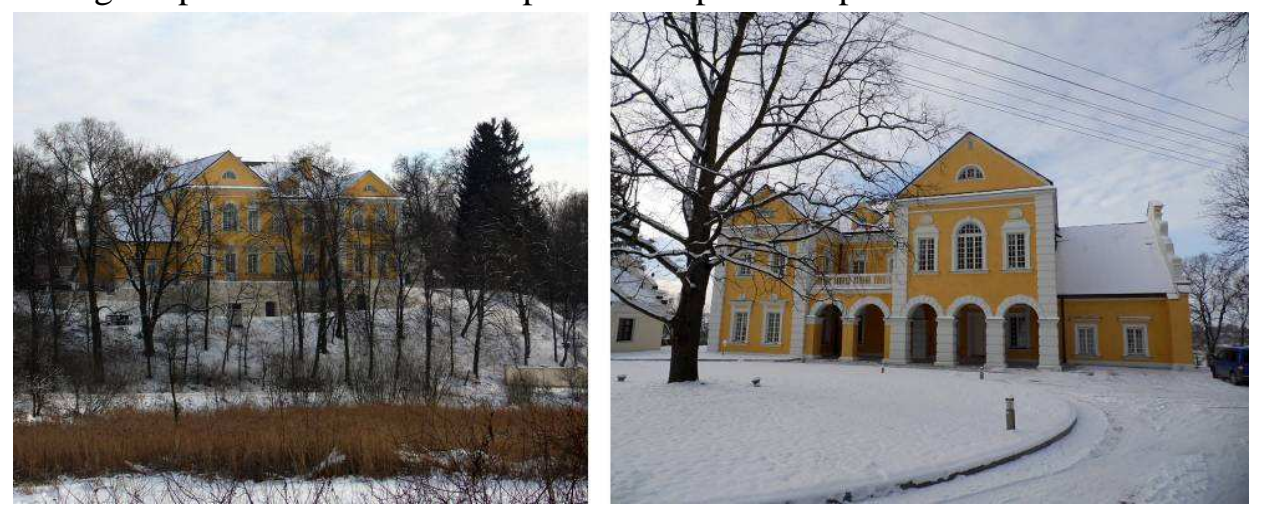

Fig. 3. Gardzienice Palace (author's photo)

The Centre adapted not only the former palace, but also the entire historical grounds around it, including the outlying buildings. All of this was made possible largely through EU funding and the involvement of the Centre itself. Gardzienice can be proud of the place, visited by guests from Poland as well as from all around the world.

\section{HUGE POTENTIAL IN SMALL BUILDINGS}

Piaski is a small town in the Lublin Province on the way from Lublin to Zamość. Its more recent history is closely linked with its Jewish population, while traces of the first settlements of today's Piaski date as far back as the Palaeolithic era [6]. In addition to the many historic buildings along the main street, as well as the church which today operates as a temple, Piaski is home to the ruins of a Protestant church (Fig. 4). 
The Polish Brethren, a name also used to define a faction of the Reformation in Poland, were one of the most interesting religious and social movements in Poland. The first official synod of Polish Brethren was held in 1562, and the last in 1662 [2]. It was at the end of their activities, in 1649, that an Evangelical and Reformed church was devoted in Piaski [6], the ruins of which are located near the Piaski fish ponds, by the town's football pitch. After the exile of the Polish Brethren from the Republic of Poland, the buildings served as a temple for masses and greater services. As time passed, though, it slowly began to fall into ruin. Julian Grzesik writes "(...) the Protestant church temple was built in the years 1783 to 1785 " [2]. The building itself was built of white stone, partly of brick, covered with tiles and sheet metal and with the entrance facing east and surrounded by a high wall, with an entry gate. It was a place of worship when Piaski belonged to the Protestant religion. Next to the church stood wooden school buildings, for the nobility and choirboys, as well as a shelter for the poor [1].

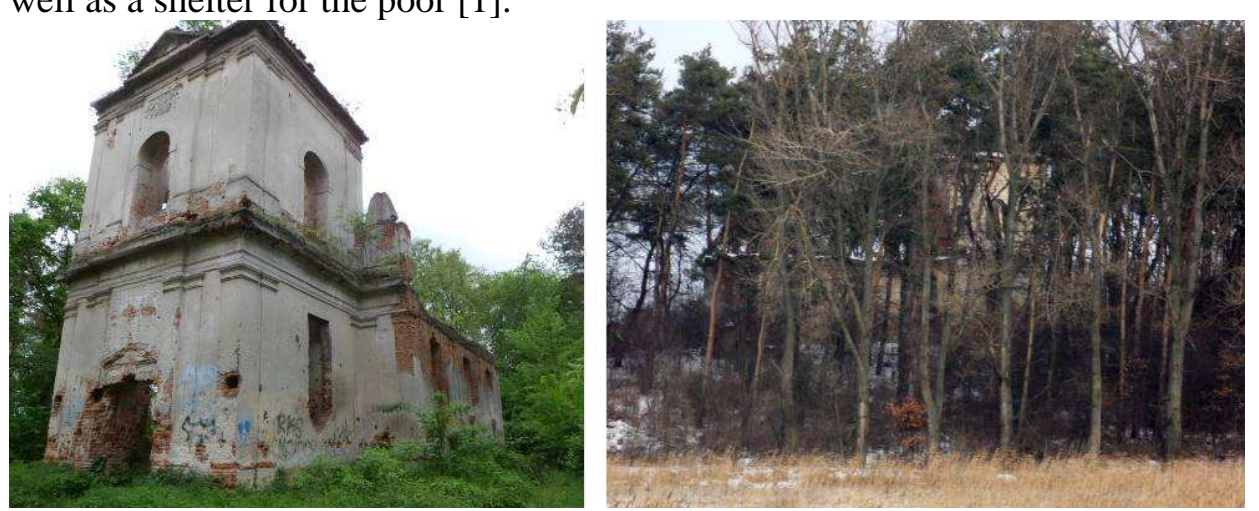

Fig. 4. The ruins of the old Protestant church in Piaski (author's photo)

Today, dense vegetation and overgrowth does not allow for proper appreciation of the complex architectural value that the former Protestant church in Piaski undoubtedly still retains. Left unattended, it has been deprived of its roof, window frames and some of the plasterwork. There are also only traces left of its surrounding walls, which are difficult to find in the dense vegetation on Kościelec Hill. However, Piaski's municipal authorities have undertaken the revitalization of this element of their city's history with a planned investment that aims to renew and adapt the old church to a new function [8]. As part of a workshop entitled Planning for Real, a 1:200 scale model of the church and its surroundings has been built (Fig. 5), to be used as the centrepiece of discussion with local activists and residents of the area about its possible future uses. 

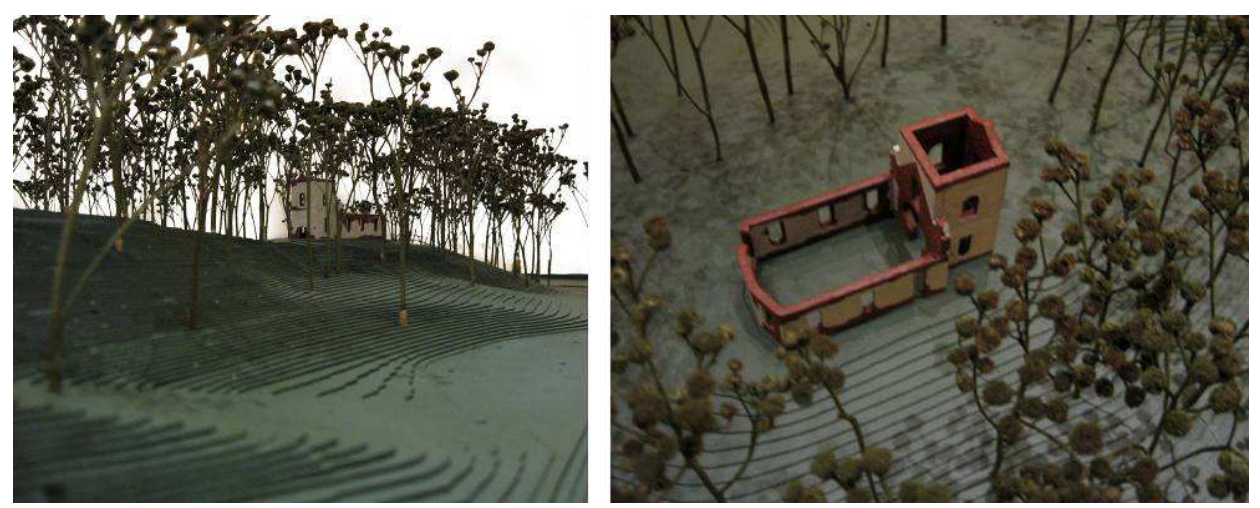

Fig. 5. A model of the ruins of the Protestant church and its surroundings in Piaski (photo: 'MODEL IN SCALE' by Piotr Jezierski)

\section{CONCLUSIONS}

Using the examples presented in this paper, the authors have shown the potential of often forgotten buildings. By highlighting some successful revitalisation projects and adaptations of original purposes to completely new ends, they have also pointed out the opportunities those buildings present.

They have focused particularly on the remains of the former Protestant church in Piaski, southeast Poland, which is currently undergoing the adaptation process. Although the current state of preservation of the old Protestant church leaves much to be desired, it is worth noting that the local authorities have taken steps to save this historic place. An analysis is being made in order to better illustrate the site's current status, using a scale model and a planned debate on the potential of the area. This is, in general, a good way of revitalizing old and abandoned buildings of historical character, and in this case creates the possibility of adapting the old church building in the most functional and attractive way.

As noted by the authors of the article in the section on the Sobieski Palace Restoration Project in Lublin, in order to emphasize the historical form and values of such buildings in the best way, the historical and historically important elements should be complemented and incorporated into the new design [7].

It is important to take note of deteriorating or ruined buildings, especially interesting or historical buildings, and by giving them new functionality make them more attractive, and add value to their region and locality. They can then even become vital elements, attracting both tourists and locals. 


\section{REFERENCES}

1. Gołaszewski Z.: Bracia polscy, Dom Wydawniczy DUET, Toruń 2004, 4-5.

2. Grzesik J.: Wybiorcza historia o zborach protestanckich $w$ Piaskach, Siedliskach $i$ Betżycach XVI-XVII wieku, LIBER Duo S.C. Publishing House, Lublin 2011, 132-143.

3. Gyurkovich J.: Architektura sakralna - wspótczesne tendencje w kościele zachodnim, Przestrzeń i Forma, 12 (2009), 173-186.

4. Jarocka-Mikrut A., Gleń P.: Poszanowanie miejsca w krajach słowiańskich $w$ kontekście architektury sakralnej, Problemy Sławianowiedienija, wydawnictwo Ładomir, 16 (2014), 214-229.

5. Raport z przeprowadzenia badania dotyczącego znajomości i wizerunku marki Szlak Jana III Sobieskiego, Project co-financed by Switzerland in the Framework of the Swiss program of cooperation with the new EU member states.

6. Świetlicki L.: Miasto Piaski kronikarski zapis dziejów, Piaski 1994.

7. Wrana Jan, Fitta Agnieszka:, Sobieski palace in Lublin after the assessment of the existing condition. Restoration and modernization project, Civil And Environmental Engineering Reports, 9 (2012), 165-174.

8. www.ofszlaksobieskiego.pl (dostęp 05.01.2015).

\section{ADAPTATION OF FORGOTTEN BUILDINGS. THE EXAMPLE OF THE RUINS OF THE KOŚCIELEC PROTESTANT CHURCH IN PIASKI}

\section{Streszczenie}

Niewielkie miejscowości województwa lubelskiego obfitują w pokaźną ilość obiektów o znaczących walorach architektonicznych jak również historycznych świadczących o kulturze zaprzeszłych pokoleń. Piaski, miasto znajdujące się na wschód od Lublina, również może poszczycić się wartymi propagowania budynkami charakterystycznymi dla niewielkich ośrodków miejskich. Mowa tutaj nie tylko o kamienicach pożydowskich jakie znajdują się w tym pożydowskim miasteczku ale również występujących na jego obrzeżach założeniach pałacowych czy sakralnych. W artykule skoncentrowano się na obiekcie sakralnym - dawnym zborze kalwińskim, który nieużytkowany popada w ruinę. Aktualnie prowadzone przez miasto prace odnośnie dawnego zboru Kościelec stały sie katalizatorem do poszukiwania najlepszej możliwej funkcji użytkowej, która powinna się znaleźć w opisywanym obiekcie tak, by umożliwić zachowanie jego wartości architektonicznych dla przyszłych pokoleń. Autorzy niniejszego artykułu pragną również dowieść konieczność prowadzenia tego typu badań oraz analiz wśród lokalnych społeczności prowadzących ku znalezieniu najlepszej funkcji dla obiektów o narzuconej 
formie architektonicznej. Podając przykład udanej rewitalizacji zespołu pałacowoparkowego w Gardzienicach położonego niedaleko od barokowego zboru w Piaskach, w niniejszym artykule przedstawione zostaja pozytywne skutki towarzyszące procesom adaptacyjnym jakim może zostać poddana wartość architektoniczna.

Słowa kluczowe: zbór kalwiński, bracia polscy, Piaski, kościelec, rewitalizacja

Editor received the manuscript: $19.10 .2014 r$. 